\title{
Is quartz a potential indicator of ultrahigh-pressure metamorphism? Laser Raman spectroscopy of quartz inclusions in ultrahigh-pressure garnets
}

\author{
ANDREY V. KORSAKOV ${ }^{1, *}$, MARIA PERRAKI ${ }^{2}$, VLADIMIR P. ZHUKOV ${ }^{3}$, KRIS DE GUSSEM $^{4}$, PETER VANDENABEELE ${ }^{5}$ \\ and ANATOLY A. TOMILENKO ${ }^{1}$ \\ ${ }^{1}$ Institute of Geology and Mineralogy of Siberian Branch Russian Academy of Sciences, Koptyug Pr. 3, \\ Novosibirsk 630090, Russia \\ *Corresponding author, e-mail: korsakov@uiggm.nsc.ru \\ ${ }^{2}$ School of Mining and Metallurgical Engineering, National Technical University of Athens, 9 Heroon Politechniou St, \\ Zografou, Athens, 15780, Greece \\ ${ }^{3}$ Institute of Computational Technologies, Siberian Branch of the Russian Academy of Sciences, \\ Acad. Lavrentjev avenue 6, 630090 Novosibirsk, Russia \\ ${ }^{4}$ Department of Analytical Chemistry Raman Research Group, Ghent University, Proeftuinstraat 86, 9000 Ghent, \\ Belgium \\ ${ }^{5}$ Department of Archaeology and Ancient History of Europe, Ghent University, Blandijnberg 2, 9000 Ghent, Belgium
}

\begin{abstract}
Laser Raman microspectroscopy was applied to quartz inclusions in coesite- and diamond-grade metapelites from the Kokchetav ultrahigh-pressure metamorphic (UHPM) complex, Northern Kazakhstan, and diamond-grade eclogite xenoliths from the Mir kimberlite pipe, Yakutiya, Russia to assess the quantitative correlation between the Raman frequency shift and metamorphic pressure. Quartz crystals sealed in garnets have a higher frequency shift than those in the matrix. Residual pressures retained by quartz inclusions depend on the metamorphic history of the garnet host. The Raman frequency shift of quartz inclusions in garnet from coesite-grade and diamond-grade metamorphic rocks shows no systematic change with increasing peak metamorphic pressures. The highest shifts of the main Raman bands of quartz were documented for monocrystalline quartz inclusions in garnets from a diamond-grade eclogite xenolith. Calibrations based on experimental work suggest that the measured Raman frequency shifts signify residual pressures of 0.1-0.6 GPa for quartz inclusions from coesite-grade metapelites from Kokchetav, 0.1-0.3 GPa for quartz inclusions from diamond-grade metapelites from Kokchetav, and 1.0-1.2 GPa for quartz inclusions from the diamondgrade eclogite xenoliths from the Mir kimberlite pipe. Normal stresses and internal (residual) pressures of quartz inclusions in garnet were numerically simulated with a 3-shell elastic model. Estimated values of residual pressures are inconsistent with the residual pressures estimated from the frequency shifts. Residual pressure slightly depends on $P-T$ conditions at peak metamorphic stage. Laser Raman microspectroscopic analysis of quartz is a potentially powerful method for recovering an ultrahigh pressure metamorphic event. Monocrystalline quartz inclusions yielding a residual pressure greater than $2.5 \mathrm{GPa}$ might indicate the presence of a former coesite.
\end{abstract}

Key-words: quartz, coesite, diamond, UHPM petrology, Raman spectroscopy, 3-shell elastic model, residual pressure.

\section{Introduction}

Ultrahigh-pressure metamorphic (UHPM) complexes are common features of suture zones of lithospheric plates (Chopin, 2003). Despite an extensive search for new UHPM indicators, coesite and diamond remain the most reliable indicators among others. Diamond inclusions are quite rare and have been identified so far only in a limited number of localities (Sobolev \& Shatsky, 1990; Massonne, 1999; Mposkos \& Kostopoulos, 2001; Van Roermund et al., 2002; Mposkos \& Krohe, 2006; Perraki et al., 2006), whereas the presence of coesite has been confirmed for 18 complexes (Chopin, 2003). Unfortunately, the complex metamorphic history of UHPM rocks often erases the peak metamorphic assemblages and prevents reliable estimation of the peak metamorphic conditions.

Since the first findings of coesite, the high-pressure $\mathrm{SiO}_{2}$ polymorph in crustal rocks (Chopin, 1984; Smith, 1984), it has become a very powerful mineral-indicator of ultrahigh-pressure metamorphism. Unlike diamonds, the presence of only one coesite inclusion undoubtedly provides evidence for an UHPM origin of the host mineral (Korsakov et al., 2004). However, due to the fast kinetics of the coesite-to-quartz transformation (Mosenfelder \& 
Bohlen, 1997; Perrillat et al., 2003 and references therein), coesite rarely survives even when it is included in robust minerals. In most cases, relics of coesite are present in the core of polycrystalline quartz aggregates, surrounded by a radial crack pattern. These partial or complete pseudomorphs of quartz after coesite are quite abundant over a wide range of lithologies. They are sometimes used together with other mineralogical indicators to prove that the rocks experienced UHP metamorphic conditions (Gilotti \& Krogh Ravna, 2002).

The most reliable method for documenting the presence of quartz and coesite is laser Raman microspectroscopy (Scott \& Porto, 1967; Sharma et al., 1981; Boyer et al., 1985). Raman band positions of minerals are known to be dependent on composition, pressure, and temperature. Quartz is generally a virtually pure end-member and it is stable over a wide range of metamorphic conditions. Hence, it is a potential Raman geobarometer. The effect of pressure and temperature on quartz Raman bands positions is experimentally well known (Hemley, 1987; Schmidt \& Ziemann, 2000). A quartz geobarometer has been calibrated recently on metamorphic quartz from quartz-eclogite, epidote-amphibolite, and amphibolitefacies rocks (Enami et al., 2007). In this paper, we study the application of the quartz geobarometer to coesite- and diamond-grade metapelites from the Kokchetav complex, Northern Kazakhstan and diamond-grade eclogite xenoliths from the Mir kimberlite pipe, Yakutiya, Russia.

\section{Experimental techniques}

Raman spectra were obtained using a Kaiser System Hololab 5000R modular Raman microspectrometer (f/1.8) (KOSI, Ecully, France). The microscope was fitted with a $100 \times$ objective (PL Fluotar L, N.A. 0.75, W.D. $4.7 \mathrm{~mm}$, Leica). Samples were excited using $45-50 \mathrm{~mW}$ of a $785 \mathrm{~nm}$ laser light from a diode laser (Toptica Photonics AG, Martinsried/ Munich, Germany). The scattered light is guided to the spectrograph through a confocal, $15 \mu \mathrm{m}$ aperture collection fibre. A back-illuminated deep depletion Pelletier cooled CCD detector (Andor, Belfast, Northern Ireland) operating at $-70{ }^{\circ} \mathrm{C}$ was used for the detection of the scattered light. The Raman signal was collected in the spectral interval of $100-3100 \mathrm{~cm}^{-1}$ with a spectral resolution of $4 \mathrm{~cm}^{-1}$. Further details of the calibration procedure can be found in Hutsebaut et al. (2005).

\section{Samples}

Five representative samples were chosen for this study (Table 1): three samples of coesite-grade mica-schists (K86, K26C, B01-3), one sample of a diamond-grade garnet-kyanite-quartz rock (B9-04) from the Kokchetav massif (Fig. 1.) and one sample of a diamond-grade eclogite xenolith (TM90-1) from the Mir pipe (Yakutiya), with different metamorphic history.

\subsection{Coesite-grade micaschist samples K86, B01-3, K26C from the Kokchetav massif}

The mineral assemblage in the studied micaschists studied here is: garnet + phengite + quartz \pm kyanite. Rutile, apatite, monazite, zircon and graphite are common accessory minerals. Phlogopite and chlorite occur as retrogressive breakdown products of garnet and kyanite. Garnet porphyroblasts generally constitute $20-40 \mathrm{vol} \%$ of the rock. They are subhedral, rounded, and equigranular with a diameter ranging from 0.2 to $5.0 \mathrm{~mm}$. Larger than $2 \mathrm{~mm}$ porphyroblasts display a sharp optical boundary between clear pinkish cores and reddish mantles and rims. The

Table 1. Mineral assemblages, $P-T$ estimates and characteristic features of garnet porphyroblasts from coesite- and diamond-grade metamorphic rocks from the Kokchetav Massif (Northern Kazakhstan) and eclogite xenolith from the Mir kimberlite pipe (Yakutiya).

\begin{tabular}{|c|c|c|c|c|c|}
\hline Sample & Locality & Mineral assemblage & \multicolumn{2}{|c|}{ peak $P-T$ conditions } & Zoning pattern in garnet \\
\hline K86 & Kulet $^{\mathrm{a}}$ & Grt, Phe, Bt, Ky, Pse, Qtz/Coe, Ilm, Rut, Chl & $600-650$ & $3.2-3.8^{\mathrm{b}}$ & Prograde \\
\hline B01-3 & Barchi-Kol ${ }^{\mathrm{e}}$ & Grt, Phe, Ky, Qtz/Coe(? ), Gr, Ilm, Rut, Chl & $600-650$ & $1.6-2.4^{\mathrm{f}}$ & Prograde \\
\hline B9-04 & Barchi-Kol $^{\mathrm{g}}$ & Grt, Phe, Bt, Ky, Qtz/Coe, Gr, Dia & $950-1000$ & $4-6^{\mathrm{h}}$ & Homogeneous \\
\hline TM90-1 & Mir pipe ${ }^{i}$ & Grt, Cpx, Dia, Qtz, Rut & $>1100-1200$ & $>5^{\mathrm{j}}$ & Homogeneous \\
\hline
\end{tabular}

\footnotetext{
${ }^{\mathrm{a}} \mathrm{N} 53^{\circ} 00^{\prime} 14.3^{\prime \prime} \mathrm{E} 69^{\circ} 30^{\prime} 16.1^{\prime \prime}$.

${ }^{\mathrm{b}}$ Parkinson (2000).

${ }^{c} \mathrm{~N} 53^{\circ} 00^{\prime} 14.3^{\prime \prime}$ E $69^{\circ} 30^{\prime} 16.1^{\prime \prime}$.

${ }^{\mathrm{d}}$ Korsakov et al. (submitted).

eN $53^{\circ} 09^{\prime} 12^{\prime \prime}$ E $68^{\circ} 40^{\prime} 14^{\prime \prime}$.

${ }^{\mathrm{f}}$ This study.

${ }^{\mathrm{g}} \mathrm{N} 53^{\circ} 09^{\prime} 07^{\prime \prime} \mathrm{E} 68^{\circ} 40^{\prime} 59^{\prime \prime}$.

${ }^{\mathrm{h}}$ Massonne (2003), Shatsky et al. (2005), Korsakov et al. (2005, 2007).

${ }^{\mathrm{i}} \mathrm{N} 62^{\circ} 31^{\prime} 42.07^{\prime \prime} \mathrm{E} 113^{\circ} 59^{\prime} 38.34^{\prime \prime}$.

${ }^{\mathrm{j}}$ Tomilenko et al. (2005).

${ }^{\mathrm{k}}$ Tomilenko et al., (2005).
} 


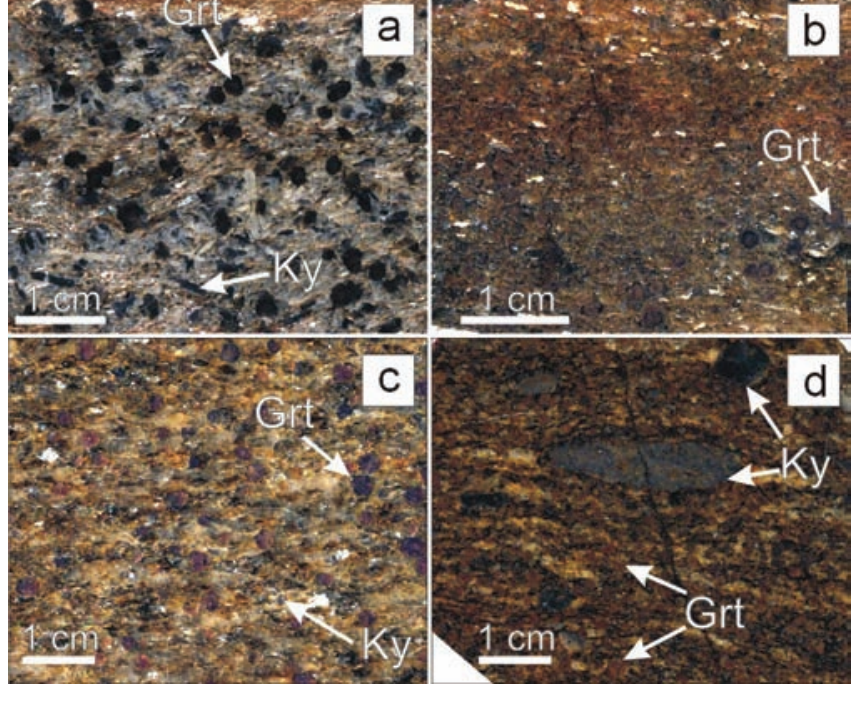

Fig. 1. Cut and polished surfaces of hand-specimens of coesite- $(a-c)$ and diamond-grade (d) metamorphic rocks from the Kokchetav massif.

small garnet grains and the mantles and the rims of the large garnet porphyroblasts contain numerous microscopic rutile rods. These rods are generally less than $1 \mu \mathrm{m}$ wide and $5 \mu \mathrm{m}$ long. Coesite-grade micaschist samples have a zonal distribution of $\mathrm{SiO}_{2}$ inclusions. Monocrystalline quartz inclusions predominantly occur in the core. Coesite or quartz pseudomorphs after coesite dominate in the external zone of the garnet porphyroblasts. Other inclusions comprise in decreasing order of abundance: rutile, ilmenite, kyanite, phengite, phlogopite, coesite, graphite, apatite and chlorite.

The three mica-schist samples (K86, B01-3, K26C) were selected because of their different garnet chemistry (Table 2) and metamorphic history (Korsakov et al., submitted).

\subsubsection{Sample $K 86$}

The sample K86 contains large garnet porphyroblasts with a manganese-rich core ( $\mathrm{MnO}$ up to $12 \mathrm{wt} \%$, Table 2.). Abundant euhedral monocrystalline quartz inclusions (Fig. 2), similar to those described by Parkinson (2000), are present. The external zone of the garnets is rich in relics of coesite surrounded by a polycrystalline quartz shell, and in polycrystalline quartz inclusions, representing pseudomorphs after coesite.

\subsubsection{Sample K26C}

Garnet porphyroblasts from the sample $\mathrm{K} 26 \mathrm{C}$ also contain abundant quartz inclusions. No prograde zoning in the garnet porphyroblasts was observed. $\mathrm{MnO}$ content is less than $1 \mathrm{wt} \%$ (Table 2). Coesite relics are present in the core of the garnet porphyroblasts. Monocrystalline quartz inclusions also occur (Fig. 3). Quartz grains behave optically as a single grain (see Korsakov et al., submitted). A weak birefringent halo is observed around some quartz

Table 2. Representative microprobe analyses of garnet porphyroblasts from coesite- and diamond-grade metamorphic rocks from the Kokchetav Massif (Northern Kazakhstan) and eclogite xenolith from the Mir kimberlite pipe (Yakutiya). c, core; r, rim.

\begin{tabular}{|c|c|c|c|c|c|c|c|c|c|c|c|}
\hline \multirow[b]{2}{*}{ Sample } & \multicolumn{2}{|c|}{ K86 } & \multicolumn{2}{|c|}{$\mathrm{K} 26 \mathrm{C}$} & \multicolumn{2}{|c|}{ B01-3 } & \multicolumn{2}{|c|}{ B9-04 } & \multicolumn{3}{|c|}{ TM90-1 } \\
\hline & $\mathrm{c}$ & $\mathrm{r}$ & $\mathrm{c}$ & $\mathrm{r}$ & $\mathrm{c}$ & $\mathrm{r}$ & $\mathrm{c}$ & $\mathrm{r}$ & $\mathrm{c}$ & $\mathrm{r}$ & Cpx \\
\hline $\mathrm{SiO}_{2}$ & 36.49 & 37.05 & 37.36 & 37.26 & 36.88 & 37.48 & 38.32 & 38.35 & 41.10 & 41.12 & 54.90 \\
\hline $\mathrm{TiO}_{2}$ & 0.03 & 0.00 & 0.02 & 0.00 & 0.00 & 0.02 & 0.08 & 0.07 & 0.02 & 0.02 & 0.10 \\
\hline $\mathrm{Al}_{2} \mathrm{O}_{3}$ & 20.34 & 20.79 & 20.75 & 20.64 & 20.55 & 20.82 & 21.31 & 22.09 & 22.90 & 22.87 & 6.20 \\
\hline $\mathrm{FeO}$ & 26.44 & 38.40 & 33.91 & 36.76 & 34.32 & 35.51 & 25.68 & 25.22 & 15.40 & 15.43 & 2.30 \\
\hline $\mathrm{MnO}$ & 12.47 & 0.29 & 0.98 & 0.36 & 3.87 & 0.50 & 0.35 & 0.37 & 0.34 & 0.35 & 0.03 \\
\hline $\mathrm{MgO}$ & 0.68 & 2.95 & 3.09 & 3.65 & 2.74 & 3.95 & 6.49 & 6.36 & 16.30 & 16.33 & 13.30 \\
\hline $\mathrm{CaO}$ & 2.62 & 0.64 & 3.64 & 1.30 & 1.33 & 1.16 & 7.13 & 7.04 & 3.80 & 3.79 & 16.70 \\
\hline $\mathrm{Na}_{2} \mathrm{O}$ & 0.10 & 0.05 & 0.00 & 0.00 & 0.05 & 0.01 & 0.05 & 0.05 & 0.04 & 0.04 & 3.80 \\
\hline $\mathrm{K}_{2} \mathrm{O}$ & 0.00 & 0.01 & 0.00 & 0.00 & 0.00 & 0.02 & 0.00 & 0.00 & 0.00 & 0.00 & 0.04 \\
\hline Total & 99.18 & 100.17 & 99.74 & 99.97 & 99.74 & 99.47 & 99.41 & 99.55 & 99.90 & 99.95 & 97.37 \\
\hline $\mathrm{Si}$ & 3.01 & 3.00 & 3.01 & 3.00 & 3.00 & 3.02 & 2.99 & 2.98 & 3.00 & 3.00 & 2.03 \\
\hline $\mathrm{Ti}$ & 0.00 & 0.00 & 0.00 & 0.00 & 0.00 & 0.00 & 0.00 & 0.00 & 0.00 & 0.00 & 0.00 \\
\hline $\mathrm{Al}$ & 1.98 & 1.98 & 1.97 & 1.96 & 1.97 & 1.98 & 1.96 & 2.02 & 1.97 & 1.97 & 0.27 \\
\hline $\mathrm{Fe}$ & 1.82 & 2.60 & 2.28 & 2.48 & 2.33 & 2.39 & 1.68 & 1.64 & 0.94 & 0.94 & 0.07 \\
\hline $\mathrm{Mn}$ & 0.87 & 0.02 & 0.07 & 0.02 & 0.27 & 0.03 & 0.02 & 0.02 & 0.02 & 0.02 & 0.00 \\
\hline $\mathrm{Mg}$ & 0.08 & 0.36 & 0.37 & 0.44 & 0.33 & 0.47 & 0.76 & 0.74 & 1.77 & 1.78 & 0.73 \\
\hline $\mathrm{Ca}$ & 0.23 & 0.06 & 0.31 & 0.11 & 0.12 & 0.10 & 0.60 & 0.59 & 0.30 & 0.30 & 0.66 \\
\hline $\mathrm{Na}$ & 0.02 & 0.01 & 0.00 & 0.00 & 0.01 & 0.00 & 0.01 & 0.01 & 0.01 & 0.01 & 0.27 \\
\hline $\mathrm{K}$ & 0.00 & 0.00 & 0.00 & 0.00 & 0.00 & 0.00 & 0.00 & 0.00 & 0.00 & 0.00 & 0.00 \\
\hline Alm & 0.61 & 0.86 & 0.76 & 0.82 & 0.78 & 0.79 & 0.56 & 0.55 & 0.31 & 0.31 & - \\
\hline Spes & 0.29 & 0.01 & 0.02 & 0.01 & 0.09 & 0.01 & 0.01 & 0.01 & 0.01 & 0.01 & - \\
\hline Pyr & 0.03 & 0.12 & 0.12 & 0.15 & 0.11 & 0.16 & 0.25 & 0.24 & 0.59 & 0.59 & - \\
\hline Grs & 0.08 & 0.02 & 0.10 & 0.04 & 0.04 & 0.03 & 0.20 & 0.19 & 0.10 & 0.10 & - \\
\hline
\end{tabular}




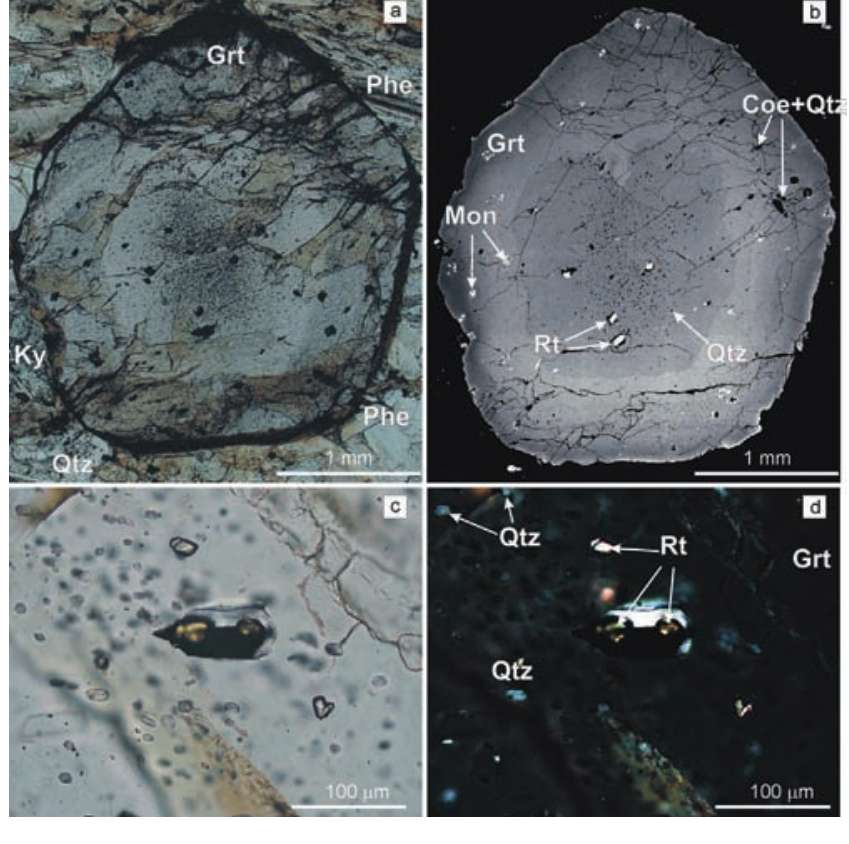

Fig. 2. Garnet porphyroblasts from the Kulet micaschists, eastern Kokchetav (sample K86). Abundant monocrystalline quartz inclusions are seen as small black spots in transmitted light photomicrograph (a) and BSE image (b). Quartz pseudomorphs after coesite, surrounded by dense radial crack patterns, can be recognized in the external mantle and rim zones. Compositional zoning with Mn-rich irregular core is observed (b). (c)-(d) Plane-polarized and crosspolarized light photomicrographs of low-pressure monocrystalline quartz in the Mn-rich core. There is no optical halo around this type of quartz inclusions.
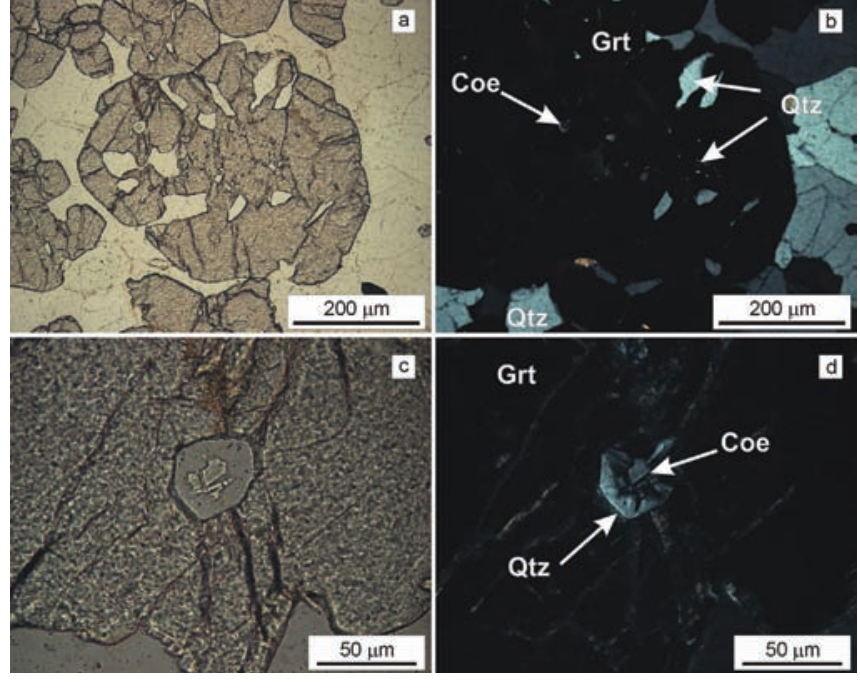

Fig. 3. Monocrystalline quartz inclusions in coesite-grade metamorphic rocks. (a-b) Plane-polarized and cross-polarized light photomicrographs of coesite inclusions coexisting in the same garnet area with monocrystalline quartz inclusions in garnet from a micaschist (sample K26C). (c-d) Plane-polarized and cross-polarized light photomicrographs of partial quartz pseudomorph after coesite with coesite relics in the core of the inclusion. inclusions. We did not find any correlations between the halo size and intensity and the size of the quartz inclusions. Large anhedral quartz inclusions (up to $1 \mathrm{~mm}$ in size) occur also in the core of such garnet porphyroblasts. No halo was observed around the large anhedral inclusions. Rare relics of coesite occur within the same growth zone and were identified by Raman spectroscopy. The mantle regions of these garnets contain quartz inclusions with palisade textures indicative of pre-existent coesite and relics of coesite (Fig. 3) coexisting side by side with both euhedral and anhedral monocrystalline quartz inclusions. Around some of these inclusions intense radial fracturing has been developed in the garnet host, whereas only very small barely visible cracks occur around others. Coesite relics in the studied samples are surrounded by a visible palisade quartz corona (Fig. 3). The thickness of the corona is highly variable even within the single samples.

\subsubsection{Sample B01-3}

Garnet porphyroblasts from the sample B01-3 preserve a prograde zonation in their core. They are characterized by a significantly lower Mn-content (only up to $5 \mathrm{wt} \%$, Table 2) compared to garnets from sample K86. Almost all quartz inclusions are characterized by an optical birefringent halo varying in intensity (Fig. 4). Some quartz inclusions are surrounded by radial crack patterns (Fig. $4 \mathrm{f}-\mathrm{e}$ ). Similar features (e.g., an optical halo and crack patterns) were observed around "monocrystalline" coesite inclusions in garnet from diamond-bearing clinozoisite gneisses (Korsakov et al., 2007).

\subsection{Diamond- and coesite-bearing garnet-kyanite-quartz-rock B9-04, from the Kokchetav massif}

Garnets from the sample B9-04 (Fig. 5) exhibit similarities in their morphology with the garnets of the sample K86 described above (Fig. 2). They have homogeneous cores whereas slight variations in their composition occur in narrow $(\sim 100 \mu \mathrm{m})$ external zones (Shatsky et al., 1995; Korsakov et al., 1998; Hermann et al., 2001; Korsakov et al., 2002; Korsakov \& Hermann, 2006). Diamond and coesite inclusions identified in the garnet porphyroblasts point to peak metamorphic conditions of $P \sim 4-6 \mathrm{GPa}$ and $T \sim 950-1000{ }^{\circ} \mathrm{C}$ (Sobolev \& Shatsky, 1990; Hermann et al., 2001; Korsakov et al., 2007). Higher peak metamorphic conditions of $P \sim 6-8 \mathrm{GPa}$ and $T=1100{ }^{\circ} \mathrm{C}$ have been reported by Ota et al. (2000), Massonne (2003) and Dobrzhinetskaya et al. (2006). Monocrystalline quartz inclusions occur in the core of garnet porphyroblasts similarly to the coesite-grade samples. Polycrystalline quartz inclusions (up to $200 \mu \mathrm{m}$ in size), representing pseudomorphs after coesite, occur predominantly within the external garnet zone. Intergrowths of monocrystalline quartz with diamond were found as inclusions in some garnets (Fig. 5c-d). No optical birefringent halo was observed around the quartz inclusions in the sample B9-04. Similar behaviour of monocrystalline quartz 

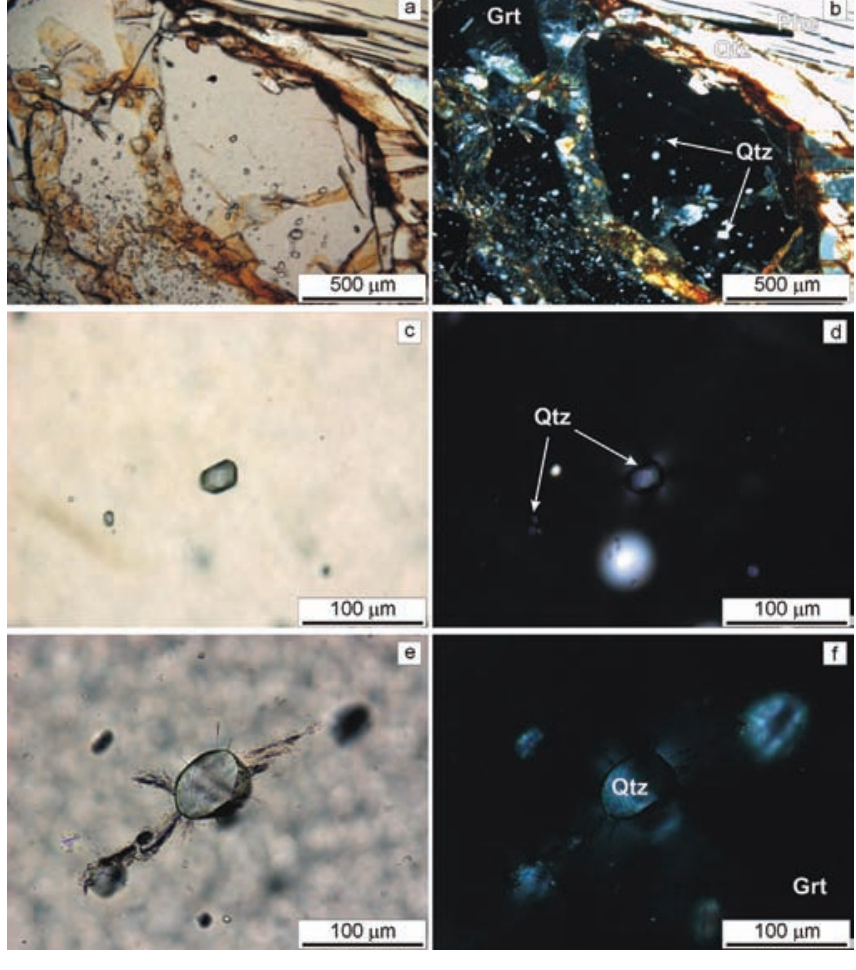

Fig. 4. Photomicrographs of high to ultrahigh (?) pressure monocrystalline quartz inclusions in garnet porphyroblast (sample B01-3). An optical birefringent halo with different intensity is observed around quartz inclusions (a)-(d). Weak halo also can be seen for partly exposed quartz inclusions (f)-(e). This inclusion is surrounded by radial crack patterns.

inclusions was observed in diamond-bearing samples from the Rhodope Massif, Greece (Mposkos et al., 2009).

\subsection{Diamond-bearing eclogite xenolith from the Mir kimberlite pipe, Yakutiya}

This rock consists of garnet and strongly altered clinopyroxene (Tomilenko et al., 2005). Only monocrystalline quartz and needles of rutile were identified as inclusions in garnet porphyroblasts (Fig. 6).

All quartz inclusions (up to $100 \mu \mathrm{m}$ ) in garnet are euhedral. They are surrounded by a very intense halo (Fig. 6). Tiny radial cracks occur at apices, probably formed due to expansion of quartz inclusions. Exposed at the thin-section surface the inclusions lose the halo and the residual pressure is partly eliminated. Sometimes, these cracks are filled with fluid (Tomilenko et al., 2005).

\subsection{Raman spectroscopic study of euhedral monocrystalline quartz inclusions}

Representative Raman spectra of monocrystalline quartz inclusions of the sample K86 are presented in Fig. 7a. There is no measurable shift of the main quartz Raman bands (Table 3). Raman spectra correspond well with

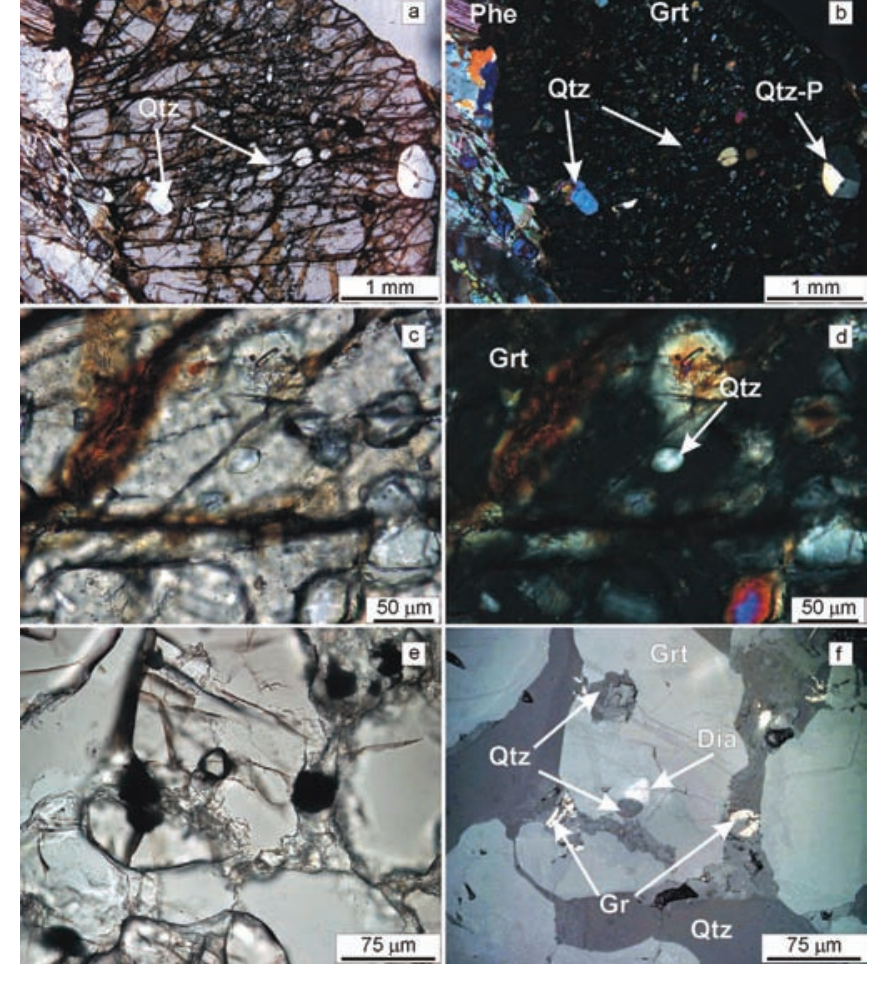

Fig. 5. Monocrystalline (Qtz) and polycrystalline (Qtz-P) quartz inclusions in diamond-grade metamorphic rocks. (a-b) Plane-polarized and cross-polarized light photographs of garnet porphyroblast with abundant monocrystalline quartz inclusions in the core. A polycrystalline quartz inclusion is identified within the external zone of garnet porphyroblast. (c-d) Plane-polarized and cross-polarized light photographs of representative monocrystalline quartz inclusion from the core of garnet crystal (no cracks or an optical halo can be seen). (e-f) Plane-polarized and reflected light photographs of an intergrowth of monocrystalline quartz and diamonds included in garnet.
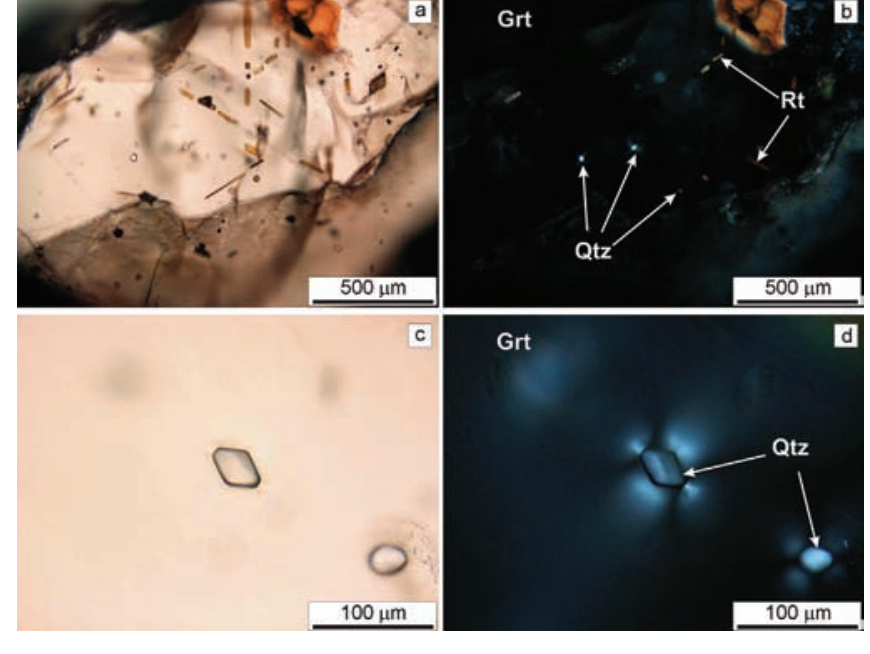

Fig. 6. Photomicrographs of rutile needles (a-b) and euhedral monocrystalline quartz inclusions surrounded by a very intense optical birefringent halo (c-d) in diamond-bearing eclogite xenolith from Mir kimberlite pipe (Yakutiya). 


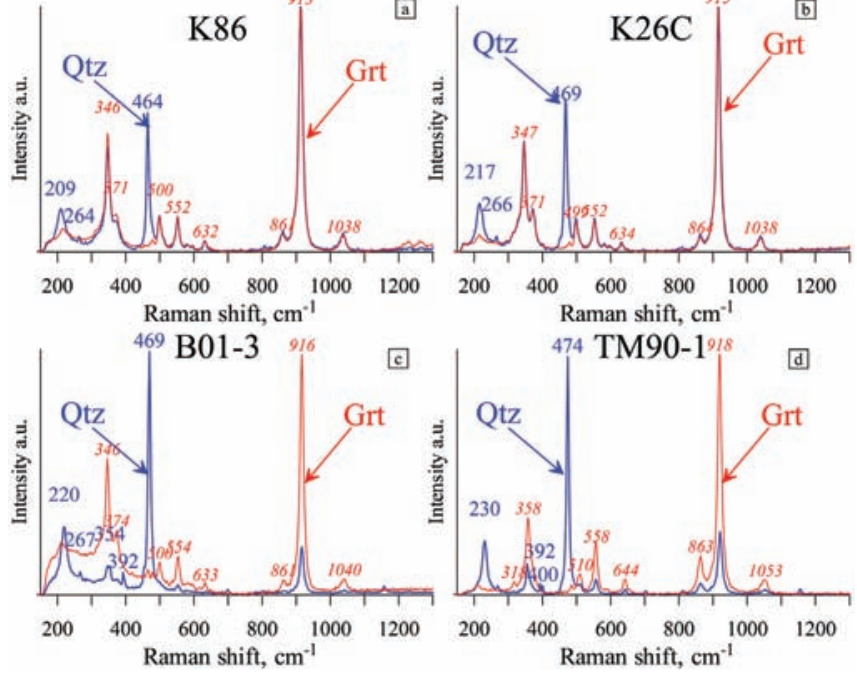

Fig. 7. Representative Raman spectra of monocrystalline euhedral quartz inclusions in garnet porphyroblast. A low residual pressure for quartz inclusions was measured for sample K86 (a), high residual pressures were documented for samples K26C (b), B01-3 (c) and TM90-1 (d).

spectra collected at ambient conditions (Scott \& Porto, 1967). There is a significant upshift of the main quartz Raman bands for all quartz inclusions in garnets from the samples K26C and B01-3 (Table 3). Representative Raman spectra are shown in Fig. 7b, c, respectively. The highest shift of the main quartz band (up to $471 \mathrm{~cm}^{-1}$ ) was measured for an unexposed quartz inclusion. For inclusions partly exposed at the surface the shift is lower (around $467-468 \mathrm{~cm}^{-1}$ ); however, these values are still higher than those for ambient pressure.

There is no measurable shift for the quartz inclusions in garnet from diamond-grade metamorphic rocks from the Kokchetav massif (Table 3). Raman spectroscopic study of the quartz inclusions in garnet from the eclogite xenolith revealed that they exhibit the highest upshift of the main quartz band, up to $474 \mathrm{~cm}^{-1}$ (Fig. $7 \mathrm{~d}$ and Table 3 ). This is the absolute maximum upshift reported so far for monocrystalline quartz inclusions in garnet.

\section{Theoretical consideration and a 3-shell elastic model}

The transformation of coesite to quartz and internal (residual) pressure in the inclusions can be modelled by a three-shelled composite sphere in linear elasticity. This model is presented below. Similar models but with different initial conditions were developed by Nishiyama (1998).

We assume that a system consisting of $j_{o}$ layers is formed at the pressure $P_{0}$ and temperature $T_{0}$. The first substance occupies a sphere of the radius $r_{l}$, the second occupies the shell $r_{1}<r<r_{2}$, the $j$-th substance occupies the shell $r_{j-1}<r<r_{j}$. We also assume that all processes are slow, so that the temperature will be uniform and the body will maintain mechanical equilibrium. The temperature of the formation is high and the stress tensor $\sigma_{i k}$ relaxes to an isotropic form: $\sigma_{r r}=\sigma_{\theta \theta}=\sigma_{\varphi \varphi}=-P_{0}$. The radial displacement in initial stage is expressed by the formula

$$
u_{0}=A_{0 j} r, \quad A_{0 j}=-P_{0} /\left(3 K_{0 j}\right)
$$

where $K_{o j}$ is the bulk modulus in the $j$-th substance in initial state. Let the system change to an environment with the pressure $P$ and temperature $T$. We assume that during this change the system has the behaviour of an elastic body. Below we indicate the component $\sigma_{r r}$ of stress tensor as $\sigma_{r}$ and $\sigma_{\theta \theta}=\sigma_{\varphi \varphi}$ as $\sigma_{t}$. It is well known (Zhang, 1998), that the conditions of equilibrium give the expression for radial

Table 3. Mean Raman shift $(\bar{v})$ of the main bands of monocrystalline euhedral quartz for coesite- and diamond-grade metamorphic rocks from the Kokchetav Massif and Mir kimberlite pipe. Pressure shifts of the Raman modes $(\mathrm{d} v / \mathrm{d} P$ ) of $\alpha$-quartz after Hemley (1987) and calculated values of residual pressure $\left(P_{i}, \mathrm{GPa}\right)$ based on the calibration.

\begin{tabular}{|c|c|c|c|c|c|c|c|c|c|c|c|}
\hline \multirow{2}{*}{$\begin{array}{l}v, \\
\mathrm{~cm}^{-1}\end{array}$} & \multirow{2}{*}{$\begin{array}{c}(\mathrm{d} v / \mathrm{d} P) \\
\mathrm{cm}^{-1} / \mathrm{GPa}\end{array}$} & \multicolumn{2}{|c|}{ K86 } & \multicolumn{2}{|c|}{$\mathrm{K} 26 \mathrm{C}$} & \multicolumn{2}{|c|}{ B01-3 } & \multicolumn{2}{|c|}{ B9-04 } & \multicolumn{2}{|c|}{ TM90 } \\
\hline & & $\bar{v}$ & $P_{i}$ & $\bar{v}$ & $P_{i}$ & $\bar{v}$ & $P_{i}$ & $\bar{v}$ & $P_{i}$ & $\bar{v}$ & $P_{i}$ \\
\hline 128 & $5.5 \pm 0.2$ & - & - & - & - & - & - & - & - & - & - \\
\hline 206 & $19.9 \pm 0.7$ & 209 & 0.15 & 217 & 0.55 & 220 & 0.70 & 207 & 0.05 & 231 & 1.26 \\
\hline 265 & $3.5 \pm 0.1$ & 264 & -0.29 & 266 & 0.29 & 267 & 0.57 & 265 & 0.00 & 269 & 1.14 \\
\hline 355 & $-1.2 \pm 0.7$ & - & - & - & - & 353 & 1.67 & - & - & & - \\
\hline 394 & $-0.09 \pm 0.03$ & - & - & - & - & 393 & 11.11 & - & - & 393 & 11.11 \\
\hline 401 & $-0.09 \pm 0.03$ & - & - & - & - & - & - & - & - & 400 & 11.11 \\
\hline 450 & $4.6 \pm 0.1$ & - & - & - & - & 454 & 0.87 & - & - & - & - \\
\hline 464 & $8.0 \pm 0.2$ & 464 & 0.00 & 468 & 0.50 & 469 & 0.63 & 464 & 0.00 & 474 & 1.25 \\
\hline 696 & $7.0 \pm 0.6$ & - & - & - & - & 700 & 0.57 & - & - & 704 & 1.14 \\
\hline 808 & $5.9 \pm 0.7$ & - & - & 809 & 0.17 & - & - & - & - & 812 & 0.68 \\
\hline 1162 & $-3.1 \pm 0.3$ & - & - & - & - & 1157 & 1.61 & - & - & 1156 & 1.94 \\
\hline \multirow{2}{*}{\multicolumn{2}{|c|}{$\begin{array}{l}\text { Optical halo } \\
\text { Radial crack pattern }\end{array}$}} & \multicolumn{2}{|c|}{ n.d. } & \multicolumn{2}{|c|}{ medium } & \multicolumn{2}{|c|}{ medium to strong } & \multicolumn{2}{|c|}{ n.d. } & \\
\hline & & \multicolumn{2}{|c|}{ n.d. } & \multicolumn{2}{|c|}{ tiny } & \multicolumn{2}{|c|}{ tiny } & \multicolumn{2}{|c|}{ n.d. } & \multicolumn{2}{|c|}{ tiny } \\
\hline
\end{tabular}


displacement $u(r)=C_{1} r+C_{2} / r^{2}$ in each layer. In our case it is more convenient to write for the $j$-th substance

$$
u=\left(A_{j}+B_{j} \frac{r_{j-1}^{3}}{r^{3}}\right) r
$$

In this notation the total displacement is $u_{\text {tot }}=u+u_{0}$. For the stress tensor we have

$$
\begin{gathered}
\sigma_{r}=3 K_{j}\left(A_{0 j}+A_{j}-\varepsilon_{j}\right)-4 G_{j} B_{j} \frac{r_{j-1}^{3}}{r^{3}} \\
\sigma_{t}=3 K_{j}\left(A_{0 j}+A_{j}-\varepsilon_{j}\right)+2 G_{j} B_{j} \frac{r_{j-1}^{3}}{r^{3}}
\end{gathered}
$$

where $\varepsilon_{j}$ is the coefficient of linear expansion due to temperature change and phase transformation; $\mathrm{A}, \mathrm{B}$ and $\mathrm{C}$ are three constants and $\mathrm{G}$ is shear modulus. Note that $\varepsilon_{j}$ can be written as $\varepsilon_{j}=\left(\rho_{0 j} / \rho_{j}\right)^{1 / 3}-1$, where $\rho_{0 j}$ is the substance density at initial temperature $T_{0}$ and zero pressure and $\rho_{j}$ is the substance density at final temperature $T$ and (may be) another phase state also for zero pressure.

The conditions of finiteness of displacement in the centre, continuity of radial displacement $u$ and normal stress tensor component $\sigma_{r}$ at the boundary between layers and the condition on the outer boundary of the body may be expressed thus:

$$
\begin{gathered}
B_{1}=0 \\
A_{j}+B_{j} w_{j}=A_{j}+1+B_{j}+1, \quad j=1, \ldots, j_{0}-1 \\
3 K_{j}\left(A_{j}+A_{0 j}-\varepsilon_{j}\right)-4 G_{j} B_{j} w_{j} \\
=3 K_{j+1}\left(A_{j+1}+A_{0 j+1}-\varepsilon_{j+1}\right)-4 G_{j+1} B_{j+1}, \\
j=1, \ldots, j_{0}-1 \\
3 K_{j 0}\left(A_{j 0}+A_{0 j 0}-\varepsilon_{j 0}\right) 4 G_{j 0} B_{j 0} w_{j 0}=-P
\end{gathered}
$$

where $w_{j}=r_{j-1}^{3} / r_{j}^{3}$. We solve this system numerically.

\section{Results of numerical modelling}

We consider that (a) the system consists of pyrope and coesite at $T_{0}$ and $P_{0}$, with coesite being completely replaced by $\alpha$-quartz and (b) at the final stage the garnethost is at ambient conditions $T=293 \mathrm{~K}$ and $P=10^{-4}$ GPa.

The mechanical properties of coesite (index coe), $\alpha$-quartz (index $q t z$ ) and pyrope are given in Table 4 .

In the diagram of Fig. 8, the dependence of the residual pressure in quartz $P_{\text {in }}$ on $T_{0}$ for different $P_{O}$ is given. The residual pressure is high (more than $3 \mathrm{GPa}$ ) due to the expansion during the coesite-to-quartz phase transition. Note that in the absence of the coesite-to-quartz transformation residual pressure does not exceed $1.5 \mathrm{GPa}$.

Garnet composition has a slight effect on its elastic properties (Bass, 1995). Our calculations showed that changes in the mechanical properties of garnet had little effect on internal pressures.

In Fig. 9 the dependence of stresses $\sigma_{r}, \sigma_{t}$ and $\hat{\sigma}$ on a radius for the case $P_{0}=6 \mathrm{GPa}, T_{0}=1300 \mathrm{~K}, r_{1}=10 \mu \mathrm{m}$, $r_{2}=1 \mathrm{~mm}$ are shown. The value $\hat{\sigma}$ corresponds to the pure pressure without shear stress. Note that in our case $\hat{\sigma}$ is constant inside a layer, but can be different in different layers, as also derived by experimental data. The optical measurements show large deformation of the pyrope near the inclusion, but the pressure measurements show small pressure up to the inclusion. The highest pressure in quartz is related to phase transition.

\section{Discussion}

Coesite-to-quartz transformation is accomplished with significant volume changes; very high residual pressures can be preserved in "monomineralic" (following the definition of Parkinson, 2000) coesite inclusions, as well as in partly transformed coesite (Parkinson \& Katayama, 1999; Sobolev et al., 2000; Ye et al., 2001; Korsakov et al., 2007). The Raman shift of quartz was recently tested on natural samples in order to estimate the effect of peak metamorphic pressure on residual pressure within the quartz inclusions (Enami et al., 2007). For different UHPM complexes the maximum upshift of the main Raman quartz bands (up to $477 \mathrm{~cm}^{-1}$ ) was documented for partly transformed coesite inclusions (Korsakov et al., 2007), corresponding to residual pressures of up to 1.6 $\mathrm{GPa}$, (using the calibration of Hemley, 1987). Unlike Enami et al. (2007), we found no correlation between the residual pressure and the size of the inclusions.

Table 4. Elastic properties of coesite, quartz and pyrope after Bass (1995), Fei (1995) and Holland \& Powell (1990). Here and below the temperature is measured in kelvins and pressure, $K$ and $G-$ in $\mathrm{GPa}$, density - in $\mathrm{g} / \mathrm{cm}^{3}$. In inclusion $\varepsilon_{p v}=\left\{\left(2.14 .10^{-5}-\right.\right.$ $\left.\left.0.02 P I K_{p y}^{2}\right)\left(T-T_{0}\right)+1.1 .10^{-8}\left(T^{2}-T_{0}^{2}\right) / 2\right\}$ and host garnet $p y=(2.141050 .02 \mathrm{P} / \mathrm{K} 2 p y)(\mathrm{TT} 0)+1.1108(\mathrm{~T} 2 \mathrm{~T} 20) / 2 / 3 \mathrm{The}$ radius of coesite/quartz inclusion is $r_{1}=10 \mu \mathrm{m}$, the radius of pyrope host is $r_{2}=1 \mathrm{~mm}$. Note, that in case $r_{1} / r_{2}<<1$ a concrete value of this ratio does not influence the results.

\begin{tabular}{lcrr}
\hline & Coesite & Quartz & Pyrope \\
\hline$K, \mathrm{GPa}$ & 113.7 & 37.8 & $150+5.3 P-0.02 T$ \\
$G, \mathrm{GPa}$ & 61.6 & 44.3 & $90+1.5 P-0.01 T$ \\
$\rho, \mathrm{g} / \mathrm{cm}^{3}$ & $6.009 /\left(2.064+2.210^{-5}(T-298)\right)$ & $6.009 /\left(2.269+2.210^{-5}(T-298)\right)$ & \\
\hline
\end{tabular}




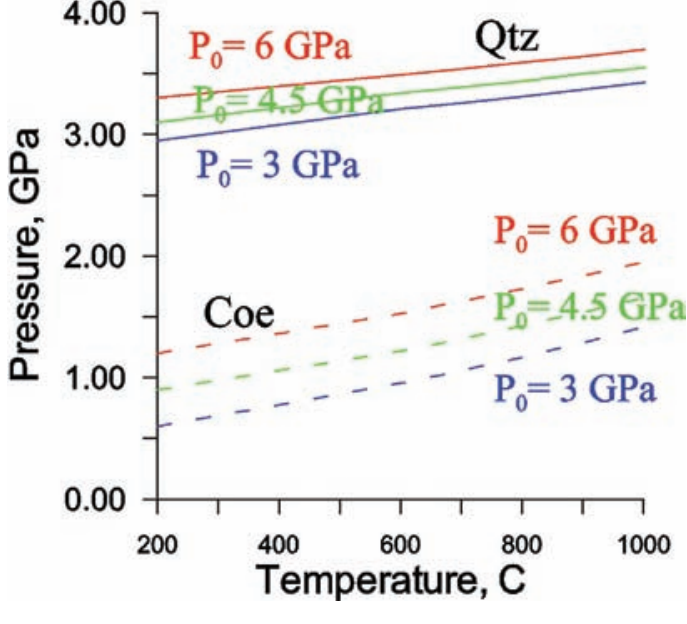

Fig. 8. Dependence of the residual pressure in coesite inclusions $P_{\text {in }}$ on $T_{O}$ for different $P_{O}$ without phase transitions (dashed lines) and quartz inclusions (solid line) formed after complete transformation to quartz of original coesite inclusions.

Ye et al. (2001) mentioned that for polycrystalline quartz pseudomorphs after coesite the Raman shift can reach $470 \mathrm{~cm}^{-1}$, corresponding to a residual pressure of $\sim 0.9 \mathrm{GPa}$. According to our numerical modelling, assuming the complete coesite-to-quartz transformation, the internal pressure for quartz pseudomorphs should be around $3.0 \mathrm{GPa}$ (depending on $P_{O}$ and $T_{O}$ ). The radial crack patterns around coesite inclusions in different minerals were interpreted to result from pressure release within the inclusion (Gillet et al., 1984; Van der Molen \& Van Roermund, 1986; Nishiyama, 1998; Zhang, 1998). Recently, it was shown that even when exposed at the thin-section surface, coesite inclusions in UHPM garnet from the Kokchetav massif still preserve high residual pressures up to $0.5 \mathrm{GPa}$ (Korsakov et al., 2007). Therefore, it is unlikely that cracks around the inclusions can cause complete relaxation of residual pressure. So far, quartz inclusions with residual pressure above $1.7 \mathrm{GPa}$ and shift above $477 \mathrm{~cm}^{-1}$ have not been documented for natural samples. This can be explained by the fact that most UHPM complexes underwent near isothermal decompression during the initial stage(s) of exhumation; therefore plastic deformation of the host garnet at $T \sim 800-900{ }^{\circ} \mathrm{C}$ is quite possible (Chen et al., 1995; Karato et al., 1995; Kleinschrodt \& Duyster, 2002; Katayama \& Karato, 2008).

Quartz inclusions in garnets from the eclogite xenolith preserved the highest values of residual pressure $\sim 1.5 \mathrm{GPa}$ and shift of the main quartz Raman bands. This is probably related to the very fast uplift of the eclogite xenolith by kimberlite melts compared to the exhumation rate of UHPM complexes (Canil \& Fedortchouk, 1999; Kelley \& Wartho, 2000; Grégoire et al., 2006). Mineral assemblages of this sample formed in the diamond stability field (Tomilenko et al., 2005) at $T=1100-1200{ }^{\circ} \mathrm{C}$ and $P>5 \mathrm{GPa}$; therefore the degree of transformation of coesite-toquartz should not be significant. Kinetics of the

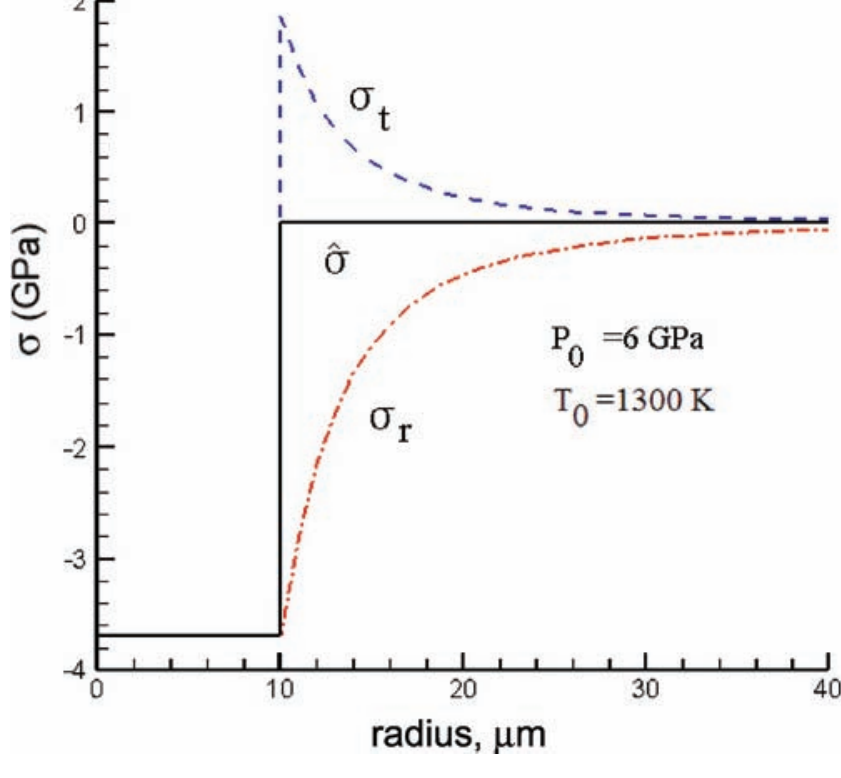

Fig. 9. Calculated radial $\left(\sigma_{r}\right)$ and tangential $\left(\sigma_{t}\right)$ stress in garnet host and quartz inclusion, originally trapped as coesite at $P_{O}=6 \mathrm{GPa}$, $T_{0}=1300 \mathrm{~K}, r_{1}=10 \mu \mathrm{m}, r_{2}=1 \mathrm{~mm}$.

coesite-to-quartz transformation are very fast at temperatures above $400{ }^{\circ} \mathrm{C}$ (Mosenfelder \& Bohlen, 1997; Perrillat et al., 2003) but the absence of dense radial crack patterns makes this transition unlikely during uplift. The exact $P-T$ conditions of the coesite-to-quartz transformation in the eclogite xenolith are unknown.

Coesite-grade micaschist samples have a zonal distribution of $\mathrm{SiO}_{2}$ inclusions. Quartz occurring in Mn-rich garnet cores was found to have low residual pressure, formed during a prograde stage of metamorphism (Fig. 10a-b). This is in a good agreement with the results of Udovkina (1985) and Parkinson (2000). The quartz crystals with higher internal pressure could also have formed during a prograde stage of metamorphism (Fig. 10c-f). However, the coexistence of these inclusions with coesite relics in the same growth zone of garnet porphyroblasts suggests that most probably they were trapped as coesite (Fig. 3). This hypothesis is further supported by the presence of quartzdiamond intergrowths included in garnet porphyroblasts from diamond-grade metamorphic rocks (Fig. 5e-f). It is worth noting that abundant coesite inclusions were found in the same thin section (Korsakov et al., 2007). A recent investigation of "wet" and "dry" transformation of coesite to quartz was performed by Lathe et al. (2005). They found that the transformation rate of "wet" coesite is more than ten times higher than that of the "dry" coesite at the same conditions. This difference may explain why some coesite crystals in our samples were completely converted to quartz, whereas others remained intact. However, in this case the coexistence of monocrystalline quartz and coesite within the same growth zone of garnet porphyroblasts can be explained only if fluid had been distributed extremely heterogeneously and had very low mobility at the UHPM stage. 

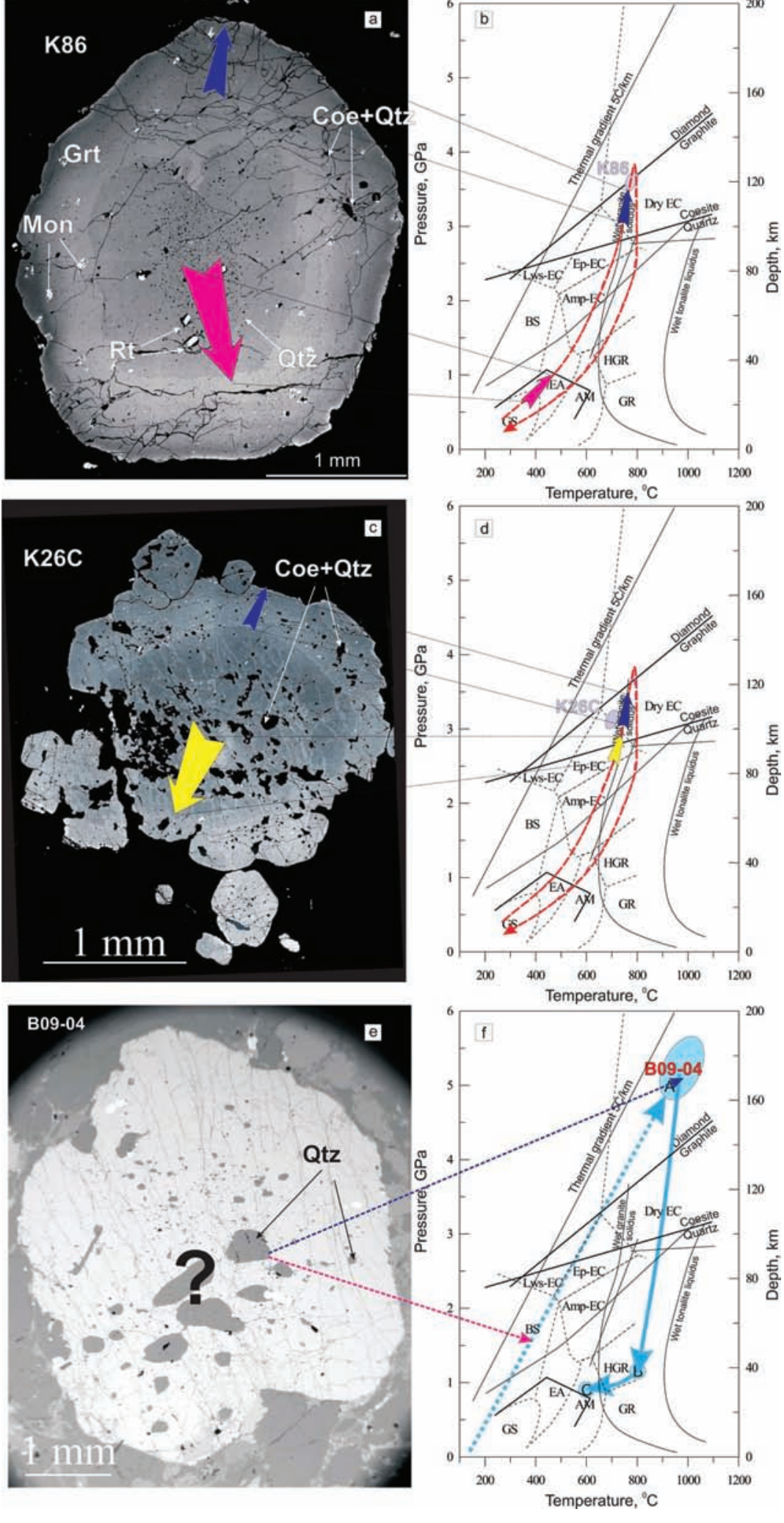

Fig. 10. BSE images of garnet porphyroblasts and $P-T$ paths for coesite- (a-d) and diamond-grade (e-f) metamorphic rocks from the Kokchetav massif plotted on metamorphic facies diagram (after Liou et al., 1998; Okamoto \& Maruyama, 1999). The $P-T$ stages indicated along the path of the coesite- and diamond-grade metamorphic rocks are based on petrologic data of Parkinson (2000), Theunissen $e t$ al. (2007) and Hermann et al. (2001), Korsakov et al. (2007), respectively. Thick arrows indicate the different stages of garnet growth. A very low subduction-zone geothermal gradient of $5{ }^{\circ} \mathrm{C} / \mathrm{km}$ is also shown. Metamorphic facies abbreviations are: $\mathrm{AM}=$ amphibolite; Amp$\mathrm{EC}=$ amphibolite-eclogite; $\mathrm{BS}=$ blueschist $\mathrm{EA}=$ epidote amphibolite $\mathrm{EC}=$ eclogite $; \mathrm{EP}-\mathrm{EC}=$ epidote-eclogite; $\mathrm{GR}=$ sillimanitebearing granulite; $\mathrm{GS}=$ greenschist; HGR = kyanite-bearing granulite; $\mathrm{P}=$ prehnite; $\mathrm{PA}=$ pumpellyite-actinolite; $\mathrm{PP}=$ prehnite-pumpellyite; and ZE = zeolite. 


\section{Concluding remarks}

Euhedral monocrystalline quartz inclusions in garnets from metamorphic rocks recrystallized under diamondand coesite-facies conditions, that

(a) are not exposed at the polished thin-section surface,

(b) lack strong radial crack patterns,

(c) have a coesite shape or a negative crystal shape of the garnet host and

(d) are surrounded by a birefringent halo, might be potential UHPM indicators.

High residual pressures of $0.8-1.2 \mathrm{GPa}$ in euhedral monocrystalline quartz inclusions with the above-mentioned characteristics are derived from the Raman shift of the main quartz band varying from 469 to $474 \mathrm{~cm}^{-1}$. The stronger the birefringent halo around such inclusions, the higher is the upshift of the main quartz Raman band. Numerical modelling indicates that complete transformation of coesite to quartz should create significantly higher residual pressure of approximately 3.0 GPa. The absence of such inclusions in natural samples may indicate that plastical deformation of the host garnet during a retrograde metamorphic stage reduces the residual pressure within the inclusion.

Summarizing the results of this study, we suggest that:

- Monocrystalline quartz inclusions with residual pressure up to 1.2 GPa (shift of the main quartz Raman band up to $474 \mathrm{~cm}^{-1}$ ) might be considered as indirect evidence for UHPM conditions.

- Monocrystalline quartz inclusions with residual pressure above $2.5 \mathrm{GPa}$ would clearly indicate that these quartz inclusions were coesite, which transformed to quartz.

Acknowledgements: Prof. M. Enami and an anonymous reviewer are thanked for their constructive comments. The editorial handling of Dr. S. Cuthbert is highly appreciated. This work was supported by the Russian Foundation for Basic Research (07-05-00308-a), MK259.2008.5, Russian Science Support Foundation. K.D.G. acknowledges the support of the Special Research Fund UGent (01P02107).

\section{References}

Bass, J.D. (1995): Elasticity of minerals, glasses, and melts. American Geophysical Union, Washington, DC, 45-63.

Boyer, H., Smith, D.C., Chopin, C., Lasnier, B. (1985). Raman microprobe (rmp) determinations of natural and synthetic coesite. Phys. Chem. Minerals, 12, 45-48.

Canil, D. \& Fedortchouk, Y. (1999): Garnet dissolution and the emplacement of kimberlites. Earth Planet. Sci. Lett., 167, 227-237.

Chen, J., Wang, Q., Zhai, M., Ye, K. (1995): Plastic deformation of garnet in eclogite. Sci. China (Series D), 39, 18-25.
Chopin, C. (1984): Coesite and pure pyrope in high-grade blueschists of the Western Alps: a first record and some consequences. Contrib. Mineral. Petrol., 86, 107-118.

Chopin, C. (2003): Ultrahigh-pressure metamorphism: tracing continental crust into the mantle. Earth Planet. Sci. Lett., 212, 1-14.

Dobrzhinetskaya, L.F., Wirth, R., Green, II, H.W. (2006): Nanometric inclusions of carbonates in Kokchetav diamonds from Kazakhstan: A new constraint for the depth of metamorphic diamond crystallization. Earth Planet. Sci. Lett., 243, 85-93.

Enami, M., Nishiyama, T., Mouri, T. (2007): Laser Raman microspectrometry of metamorphic quartz: a simple method for comparison of metamorphic pressures. Am. Mineral., 92, 1303-1315.

Fei, Y. (1995): Thermal expansion. American Geophysical Union, Washington, DC, 29-44.

Gillet, P., Ingrin, J., Chopin, C. (1984): Coesite in subducted continental crust: P-T history deduced from an elastic model. Earth Planet. Sci. Lett., 70, 426-436.

Gilotti, J.A. \& Krogh Ravna, E.J. (2002). First evidence for ultrahigh-pressure metamorphism in the North-East Greenland Caledonides. Geology, 30, 551-554.

Grégoire, M., Rabinowicz, M., Janse, A. (2006): Mantle mush compaction: a key to understand the mechanisms of concentration of kimberlite melts and initiation of swarms of kimberlite dykes. J. Petrol., 47, 631-646.

Hemley, R.J. (1987). Pressure dependence of Raman spectra of $\mathrm{SiO}_{2}$ polymorphs: $\alpha$-quartz, coesite, and stishovite. Terrapub, TokyoAGU, Washington, DC, 347-359.

Hermann, J., Rubatto, D., Korsakov, A., Shatsky, V.S. (2001): Multiple zircon growth during fast exhumation of diamondiferous, deeply subducted continental crust (Kokchetav massif, Kazakhstan). Contrib. Mineral. Petrol., 141, 66-82.

Holland, T. \& Powell, R. (1990): An enlarged and updated internally consistent thermodynamic dataset with uncertainties and correlations: the system $\mathrm{K}_{2} \mathrm{O}-\mathrm{Na}_{2} \mathrm{O}-\mathrm{CaO}-\mathrm{MgO}-\mathrm{MnO}-\mathrm{FeO}-\mathrm{Fe}_{2} \mathrm{O}_{3}-\mathrm{Al}_{2}$ $\mathrm{O}_{3}-\mathrm{TiO}_{2}-\mathrm{SiO}_{2}-\mathrm{C}-\mathrm{H}_{2}-\mathrm{O}_{2}$. J. Metamorphic Geol., 8, 89-124.

Hutsebaut, D., Vandenabeele, P., Moens, L. (2005): Evaluation of an accurate calibration and spectral standardization procedure for Raman spectroscopy. Analyst, 130, 1204-1214.

Karato, S.-I., Wang, Z., Liu, B., Fujino, K. (1995): Plastic deformation of garnets: systematics and implications for the rheology of the mantle transition zone. Earth Planet. Sci. Lett., 130, $13-30$.

Katayama, I. \& Karato, S.-I. (2008): Effects of water and iron content on the rheological contrast between garnet and olivine. Phys. Earth Planet. Inter., 166, 57-66.

Kelley, S.P. \& Wartho, J.A. (2000): Rapid kimberlite ascent and the significance of Ar-Ar ages in xenolith phlogopites. Science, 289, 609-611.

Kleinschrodt, R. \& Duyster, J.P. (2002): HT-deformation of garnet: an EBSD study of granulites from Sri Lanka, India and the Ivrea zone. J. Struct. Geol., 24, 1829-1844.

Korsakov, A.V. \& Hermann, J. (2006): Silicate and carbonate melt inclusions associated with diamonds in deeply subducted carbonate rocks. Earth Planet. Sci. Lett., 241, 104-118.

Korsakov, A.V., Shatsky, V.S., Sobolev, N.V. (1998): The first finding of coesite in eclogites of the Kokchetav massif. Dokl. Akad. Nauk, 360, 77-81.

Korsakov, A.V., Shatsky, V.S., Sobolev, N.V., Zayachkovsky, A.A. (2002): Garnet-biotite-clinozoisite gneisses: a new type of 
diamondiferous metamorphic rocks of the Kokchetav massif. Eur. J. Mineral., 14, 915-929.

Korsakov, A.V., Theunissen, K., Smirnova, L.V. (2004): Intergranular diamonds derived from partial melting of crustal rocks at ultrahigh-pressure metamorphic conditions. Terra Nova, 16, 146-151.

Korsakov, A.V., Vandenabeele, P., Theunissen, K. (2005): Discrimination of metamorphic diamond populations by Raman spectroscopy (Kokchetav, Kazakhstan). Spectrochim. Acta A, 61, 2378-2385.

Korsakov, A.V., Hutsebaut, D., Theunissen, K., Vandenabeele, P., Stepanov, A.S. (2007): Raman mapping of coesite inclusions in garnet from the Kokchetav Massif (Northern Kazakhstan). Spectrochim. Acta A, 68, 1046-1052.

Lathe, C., Koch-Müller, M., Wirth, R., Van Westrenen, W., Mueller, H.-J., Schilling, F., Lauterjung, J. (2005): The influence of OH in coesite on the kinetics of the coesite-quartz phase transition. Am. Mineral., 90, 36-43.

Liou, J., Zhang, R.Y., Ernst, W.G., Rumble, III, D., Maruyama, S. (1998): High pressure minerals from deeply subducted metamorphic rocks. Rev. Mineral., 37, 33-96.

Massonne, H.-J. (1999): A new occurrence of microdiamonds in quartzfeldspathic rocks of the Saxonian Erzgebirge, Germany and their metamorphic evolution. in "Proceedings of 7th International Kimberlite conference", 2, 533-539.

Massonne, H.-J. (2003): A comparison of the evolution of diamondiferous quartz-rich rocks from the Saxonian Erzgebirge and the Kokchetav massif: are so-called diamondiferous gneisses magmatic rocks?. Earth Planet. Sci. Lett., 216, 347-364.

Mosenfelder, J.L. \& Bohlen, S.R. (1997): Kinetics of the coesite to quartz transformation. Earth Planet. Sci. Lett., 153, 133-147.

Mposkos, E.D. \& Kostopoulos, D.K. (2001): Diamond, former coesite and supersilicic garnet in metasedimentary rocks from the Greek Rhodope: a new ultrahigh-pressure metamorphic province established. Earth Planet. Sci. Lett., 192, 497-506.

Mposkos, E.D. \& Krohe, A. (2006): Pressure-temperature-deformation paths of closely associated ultra-high-pressure (diamond-bearing) crustal and mantle rocks of the Kimi complex: implications for the tectonic history of the Rhodope Mountains, northern Greece. Can. J. Earth Sci., 43, 1755-1776.

Mposkos, E.D., Perraki, M., Palikari, S. (2009): Single and multiphase inclusions in metapelitic garnets of the Rhodope Metamorphic Province, NE Greece. Spectrochim. Acta A Mol. Biomol. Spectrosc., 73, 477-483.

Nishiyama, T. (1998): Kinetic modeling of the coesite-quartz transition in an elastic field and its implication for the exhumation of ultrahigh-pressure metamorphic rocks. The Island Arc, 7, 70-81.

Okamoto, K. \& Maruyama, S. (1999): The high pressure synthesis of lawsonite in the MORB $+\mathrm{H}_{2} \mathrm{O}$ system. Am. Mineral., 84, 362-373.

Ota, T., Terabayasgi, M., Parkisnon, C.D., Masago, H. (2000): Thermobaric structure of the Kokchetav ultra- highpressure-high-pressure massif deduce from a north south transect in the Kulet and Saldat-Kol regions, northern Kazakhstan. The Island Arc, 9, 328-357.

Parkinson, C.D. (2000): Coesite inclusions and prograde compositional zonation of garnet in whiteschist of the HP-UHPM Kokchetav massif, Kazakhstan: a record of progressive UHP metamorphism. Lithos, 52, 215-233.

Parkinson, C.D. \& Katayama, I. (1999): Present-day ultrahigh-pressure conditions of coesite inclusions in zircon and garnet: evidence from laser Raman microspectroscopy. Geology, 27, 979-982.
Perraki, M., Proyer, A., Mposkos, E., Kaindl, R., Hoinkes, G. (2006): Raman micro-spectroscopy on diamond, graphite and other carbon polymorphs from the ultrahigh-pressure metamorphic Kimi Complex of the Rhodope Metamorphic Province, NE Greece. Earth Planet. Sci. Lett., 241, 672-685.

Perrillat, J.P., Daniel, I., Lardeux, J.M., Cardon, H. (2003): Kinetics of the coesite-quartz transition: application to the exhumation of ultrahigh-pressure rocks. J. Petrol., 44, 773-788.

Schmidt, C. \& Ziemann, M.A. (2000): In-situ Raman spectroscopy of quartz: a pressure sensor for hydrothermal diamond-anvil cell experiments at elevated temperatures. Am. Mineral., 85, 1725-1734.

Scott, J.F. \& Porto, S. (1967): Longitudinal and transverse optical lattice vibrations in quartz. Phys. Rev., 161, 903-910.

Sharma, S.K., Mammone, J.F., Nicol, M.F. (1981): Raman investigation of ring configurations in vitrous silica. Nature, 292, 140-141.

Shatsky, V.S., Sobolev, N.V., Vavilov, M.A. (1995): Diamondbearing metamorphic rocks of the Kokchetav massif (Northern Kazakhstan). Cambridge University Press, Cambridge, 427-455.

Shatsky, V.S., Sobolev, N.V., Korsakov, A.V., Ragozin, A.L., Zayachkovsky, A.A. (2005): New microdiamonds locality within the Kokchetav massif (Northern Kazakhstan). Mitt. Österr. Mineral. Ges., 150, 93.

Smith, D.C. (1984): Coesite in clinopyroxene in the Caledonides and its implications for geodynamics. Nature, 310, 641-644.

Sobolev, N.V., Fursenko, B.A., Goryainov, S.V., Shu, J.F., Hemley, R.J., Mao, H.K., Boyd, F.R. (2000): Fossilized high-pressure from the earth's deep interior - the coesite-in-diamond barometer. Proc. Nat. Acad. Sci. U. S. A., 97, 11875-11879.

Sobolev, N.V. \& Shatsky, V.S. (1990): Diamond inclusions in garnets from metamorphic rocks: a new environment for diamond formation. Nature, 343, 742-746.

Theunissen, K., Korsakov, A.V., Dobretsov, N.L. (2007): Unusual garnet-coesite/quartz textures and the early exhumation of silica-rich UHP crustal rocks of Kulet (Kokchetav, Kazakhstan). Rend. Soc. Geol. Ital. Nuova Serie, V, 206.

Tomilenko, A.A., Kovyazin, S.V., Pokhilenko, N.P. (2005): Primary crystalline and fluid inclusions in garnet from diamondiferous eclogite from kimberlite pipes Mir and Udachnaya, Yakutiya, Russia. in. "ECROFI XVIII. European current research on fluid inclusions", Siena, Italy, July 6-9, 2005, CD-ROM.

Udovkina, N.G. (1985): Eclogites of the USSR. Nauka Press, Moscow. Van der Molen, I. \& Van Roermund, H.L. (1986): The pressure path of solid inclusions in minerals: the retention of coesite inclusions during uplift. Lithos, 19, 317-324.

Van Roermund, H., Carswell, D.A., Drury, M.R., Heijboer, T.C. (2002): Microdiamonds in megacrystic garnet websterite pod from Bardane on the island of Fjortoft, western Norway: evidence for diamond formation in mantle rocks during deep continental subduction. Geology, 30, 959-962.

Ye, K., Liou, J.B., Cong, B., Maruyama, S. (2001): Overpressures induced by coesite-quartz transition in zircon. Am. Mineral., 86, 1151-1155.

Zhang, Y. (1998). Mechanical and phase equilibria in inclusion-host systems. Earth Planet. Sci. Lett., 157, 209-222.

Received 19 January 2009

Modified version received 29 October 2009

Accepted 9 November 2009 